\title{
Assessing teachers' systems thinking skills during a professional development program in Turkey
}

\author{
Armagan Ateskan, PhD *, Jennie F. Lane, PhD \\ Bilkent University Graduate School of Education, Bilkent, Ankara, 06800, Turkey
}

\section{A R T I C L E I N F O}

\section{Article history:}

Received 7 July 2016

Received in revised form

11 May 2017

Accepted 17 May 2017

Available online 18 May 2017

\section{Keywords:}

Systems thinking

Education for Sustainable Development

Professional development

In-service teacher

Community projects

\begin{abstract}
A B S T R A C T
Through effective professional development in Education for Sustainable Development (ESD), teachers can help students gain knowledge, skills, and dispositions to build and support sustainable communities. This paper shares how a university in Turkey developed, implemented, and evaluated an ESD professional development program (PDP) for in-service teachers. The evaluation focused on how the program enhanced participants' awareness of thinking in systems. Thirty-nine teachers from different parts of the country participated. The PDP took place over eight months and was launched by a five-day summer workshop that included presentations, hands-on activities, and field trips. The theme of energy was used throughout the workshop to emphasize how the environment, society, and economy are connected and interdependent. Teachers' systems thinking skills were analyzed through a pre- and post-workshop questionnaire and concept maps. Results of the questionnaire showed statistically significant differences between teachers' systems thinking scale scores before and after the workshop. Concept map analysis, however, identified that participants need more support relating concepts such as social justice to the environment and economy.
\end{abstract}

๑) 2017 Elsevier Ltd. All rights reserved.

\section{Introduction}

In preparation for facing the future, students need the knowledge, skills, and dispositions to live sustainably. As teachers are responsible for this education, they need to have the competencies for and dispositions toward including these topics in their instruction. In the final report from the Decade of Education for Sustainable Development (DESD) from 2005 to 2014, UNESCO (2014) emphasizes that continued training and stakeholder involvement is critical to ongoing success of the movement. Indeed, as a follow up to the DESD, UNESCO created the Global Action Program (GAP). ${ }^{1}$ Among their priority areas, is building capacity of and preparing teachers for Education for Sustainability (ESD).

The current study investigates a professional development program (PDP) for Education for Sustainable Development (ESD) that was conducted for in-service teachers in Turkey. McKeown (2012) comments that ESD is different than traditional teaching in that it engages students in activities that connect them to real

\footnotetext{
* Corresponding author.

E-mail addresses: ateskan@bilkent.edu.tr (A. Ateskan), jennie.lane@bilkent.edu. tr (J.F. Lane).

${ }^{1}$ http://en.unesco.org/gap.
}

world issues. Educational researchers have provided a variety of guidelines for ESD (e.g., Arbuthnott, 2009; Hopkins and McKeown, 1999; Venkataraman, 2009). Around the world, organizations have been formed to provide professional development in sustainability (e.g., Facing the Future ${ }^{2}$; The Sustainable Schools Project $^{3}$; $\mathrm{UNESCO}^{4}$ ). ESD stresses the importance of environment, society, and the economy as part of the educational process. Various models for how these three areas-environment, society, and economy-interact have been proposed, including the nested model where the environment encompasses the economy that affects society (Scott-Cato, 2009).

Studies that include frameworks and guidelines for teacher competencies in ESD frequently include systems thinking as a key skill (Bertschy et al., 2013; Frisk and Larson, 2011; Gadotti, 2010; Sandri, 2013; Rauch and Steiner, 2013; Sleurs, 2008; Warren et al., 2014). Systems thinking has also been listed among the 21st century thinking skills (Binkley et al., 2012). Given the frequent inclusion of systems thinking skills as a competency for ESD, the researchers decided that the PDP should feature strategies to

\footnotetext{
2 www.facingthefuture.org.

3 sustainableschoolsproject.org.

4 www.unesco.org/education/tlsf/.
} 
promote teachers' skills in thinking in systems.

\section{Theoretical background}

In this study, the theme of energy was used to weave the golden thread of ESD through a teacher professional development program. The researchers examined several aspects of teachers' learning experiences, focusing on systems thinking. There are many explanations of systems thinking and debates about what it entails (e.g., Arnold and Wade, 2015; Assaraf and Orion, 2005; Cabrera et al., 2008; De Haan, 2010; Rieckmann, 2012; Sweeney and Sterman, 2000; Wiek et al., 2015; Wiek et al., 2011). Generally, it involves appreciating the interactions among issues within society, economy, and the environment and requires the ability to think in systems (Sweeney and Sterman, 2007). Systems thinking is seeing, valuing, and anticipating the interactions among living and nonliving things. It includes the skill of understanding and sometimes predicting outcomes of relationships and networks (Senge et al., 2000). People who think this way appreciate how humans are part of a global ecology; what we consume and what we throw away must be integrated sustainably into the global system for our long-term survival (Conca, 2001; Dobers and Strannegård, 2005; Heller and Keoleian, 2003; Rees, 2008; Sheth et al., 2011; Worts, 2006).

Three studies helped form the theoretical background for this research. The first was a paper by Porter and Córdoba (2009) who identified three theories for systems: Functionalist, Interpretive, and Complex Adaptive Systems. While the current study could have aspects of all three, the researchers found that the Interpretive view was most relevant. According to Porter and Córdoba, educators follow this approach when sustainability is seen as a process and participants are encouraged to examine their place within a system.

Another study was a conceptual paper by Sipos et al. (2008) on engaging the "head, hands, and heart" to develop transformative sustainability learning. Their work calls for a holist approach to education, considering the cognitive, behavior, and affective aspects of learning. They identify systems thinking as a key learning objective and recognize the role of place-based education in understanding local environments.

To further inform the framework for the current study, the authors referred to information presented by Steiner and Posh (2006). Steiner and Posch call for a paradigm shift away from the traditional single disciplinary approach "towards a holistic view involving systems thinking" (p. 879). Their study used transdisciplinary case studies to engage students in real-world problem solving. The method emphasized the importance of using perspectives from different disciplines to address environmental issues. The PDP presented in the current study also employed a multidisciplinary approach and used energy to illustrate systemic connections among issues that affect the economy, the environment, and society. The design and outcomes of the PDP are explained in section 3. The research design is found in section 4 .

The researchers also reviewed the literature to learn of studies in Turkey related to ESD in general and systems thinking education in particular. The Turkish government has developed reports about the country's pathway towards sustainable development (Turkish Republic Ministry of Development, 2012, 2015) and there have been a few studies related to the integration of ESD in the classroom (Cavas et al., 2014; Kaya and Tomal, 2011; Kilinc and Aydin, 2013; Ozel et al., 2013; Sağdıç and Şahin, 2016; Tanriverdi, 2009). Alkis (2008) notes, however, that many studies of ESD in Turkey have focused on assessing perceptions and attitudes and empirical studies are limited.

There are few studies related to Turkish teachers' systems thinking skills, but more are beginning to emerge. Karaman (2014) investigated how involvement in community service learning projects affects teachers' system thinking skills. The reflective thoughts of the participants were organized into themes that provided insights into changes in their systems thinking. They became more aware of systemic interactions among community members and critically questioned their roles in developing a sustainable urban setting. Karaarslan (2016) conducted a study of pre-service teachers' ESD thinking skills. She analyzed Turkey's science education curriculum in relation to sustainability literacy, and determined that systems thinking was a key skill needed for science teachers to become ESD educators. She identified twelve systems thinking skills and created outdoor education experiences to develop these skills and assessment tools to assess changes in skill level. One of the assessment tools she developed-a rubric that helps analyze concept maps for the complexity of systems thinking skills-is used in the current study.

The literature review helped the researchers identify strategies to develop professional development programs in ESD. These include helping teachers build networks for communities of practice and incorporating a systems-based approach in their school systems (Ferreira and Ryan, 2012; Ferreira et al., 2009; Ferreira et al., 2007; McClam and Diefenbacher, 2015; Summers, 2013); applying concept maps and word association activities to investigate the cognitive, affective, and behavior domains of thinking (Balgopal and Wallace, 2009; Dyment et al., 2014; Nguyen et al., 2012); and using place-based education to connect teachers with their local environments and examine systemic connections in local resources (Powers, 2005; Smith, 2007). In particular, studies emphasized providing teachers with hands-on activities and opportunities to share ideas and reflect (Ateskan, 2009; LoucksHorsley et al., 2003; Shriner et al., 2009). A notable finding from the review of the literature regarding teacher PDP, is that while there are many studies related to pre-service teachers and ESD, research related to in-service teachers is limited. Therefore, this study will contribute to the literature by reporting on strategies to provide ESD professional development experiences for practicing teachers.

\section{Teacher education in ESD: a professional development workshop in Turkey}

The PDP was conducted by faculty within the Graduate School of Education of Bilkent University, a private university in Ankara, Turkey. The researchers received funds from one of the nation's research granting agencies, the Scientific and Technological Research Council. Experts in the field of energy, education and environmental justice were invited to present at the workshop. The project started in June 2015 with a one-week workshop and culminated with a project fair in May 2016. During the fair, the teacher participants showcased the community ESD projects they conducted with students during the school year.

\subsection{Participants}

The PDP included 39 teachers ( 28 females and 11 males). In their application to the program, they reported their subject areas as science (46.2\%), elementary (who teach all subject areas) (35.9\%), mathematics (10.3\%), and social studies (7.7\%). Their teaching experience ranged from one to 36 years. Almost half (51.3\%) of the participants have $1-10$ years of teaching experience, whereas $5.1 \%$ of them have over 25 years of experience. The participants were from different regions of Turkey: Aegean (2.6\%), Black Sea (7.7\%), Central (51.3\%), Eastern (2.6\%), Marmara (23.1\%), Mediterranean (10.3\%), Southeastern (2.6\%). 


\subsection{Program design and content}

The program began with a five-day workshop, followed by community involvement projects, and ended with a project fair. The participants received continuous support for their community projects from workshop leaders and each other through e-mail and social media for the eight months between the workshop and fair. Fig. 1 illustrates how the various components interacted to support and sustain teacher learning and involvement. The workshop was designed to address the triple bottom line of sustainability: economy, society, and the environment. The theme of energy was used to tie the three areas of sustainability together.

Several activities in the workshop addressed the environmental aspects of sustainability. These included an activity where teachers were challenged to think of creative alternatives to handle materials normally thrown away. More than recycling, they thought of clever ways to reuse and repurpose items such as bottle caps, tea pots, and confetti. The teachers were reminded of the energy costs of producing and recycling and discussed how reusing saves (embodied) energy.

Another environmental activity was when a local birding expert led the teachers on a bird watching trip to gain a better understanding of Turkey's place in international bird migrations. When challenged to relate bird watching to energy, teachers identified how changes in seasons affect migration. They also mentioned energy from food, used in flight, and to maintain proper body temperature.

A field trip to Turkey's first platinum Leadership in Energy and Environmental Design (LEED) certified building highlighted how green buildings contribute to a sustainable economy. They also visited a local waste management plant (Mamak) to learn how waste is managed in Ankara, including recycling and anaerobic digestion to produce electricity and heat.

Teachers gained hands-on experiences using sustainable energy technologies by designing solar ovens out of cardboard boxes and creating solar-powered model cars from recycled materials. In both cases, teachers worked in interdisciplinary teams to share ideas and different perspectives (Steiner and Posh, 2006). They struggled with trial and error; nonetheless, they persevered and their ovens were able to bake cookies and their cars competed in a race in the parking lot. These activities related to systems thinking as they contemplated cause and effect and how different parts of their designs affected each other.

To explore sustainability and society, the teachers were asked to envision a sustainable future and analyze current consumptive practices that may compromise the well-being of future generations. A local environmental lawyer provided a presentation about how environmental issues affect social justice by using cases

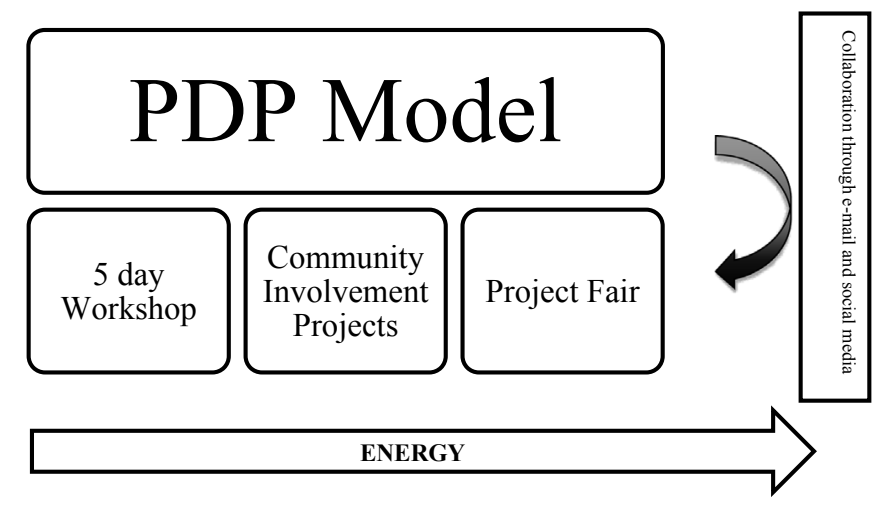

Fig. 1. PDP model. related to energy production, consumption, waste management and specific to Turkey. He also guided teachers about legal steps related to citizen action they may take with students during community involvement projects.

Further understanding of societal components of sustainability was emphasized through place-based education (PBE). According to Gruenewald (2003), understanding one's local environment is essential for sustainable development. He discusses dimensions of place, including the ecological dimension that relates to awareness of natural and human-built systems. PBE uses resources on the school ground and in local community to help students relate academic concepts to their everyday lives (Knapp, 2005; Powers, 2005: Sobel, 2004). The PBE strategies in the workshop included field trips that were either on campus or within the community (e.g., bird watching and tour of a green building). Besides demonstrating how to use local environments in ESD, the trips illustrated how energy is integral to sustainability. Each PBE activity was related to the others to help teachers develop their systems thinking skills (for example, the green building field trip included concepts that teachers could use while designing their solar ovens and cars). Throughout the workshop, teachers were encouraged to make connections among issues related to their community, their students, and their teaching profession (Porter and Córdoba, 2009).

\subsection{Program outcomes}

\subsubsection{Teacher conceptions of education for sustainability}

Near the end of the workshop, teachers were challenged to identify knowledge, dispositions, and skills that students need for ESD. Through a "world café" approach, teachers worked in interactive groups to brainstorm ideas and build consensus on flipchart paper. These papers had images of a brain or a heart or a hand drawn on them to represent knowledge, dispositions, and skills respectively (Sipos et al., 2008). Following is an overview of their understanding of what they concluded students should gain as part of ESD.

- Their "knowledge" list included the following: energy, environment and systems, molecular biology, organic farming, biotechnology, ratio and proportion, temperature, insulation, healthy life style, sustainability, probability, simple machines, soil, diversity, and matter.

- For "dispositions," they stated that students may consider human rights, responsibilities, peace, cooperation, respect, and adaptability.

- The "skills" teachers stated students need for ESD include thinking (critical, creative, reflection) and communication. They also stated the importance of being organized and disciplined. They mentioned that skills in art, mathematics, and debate are important, too.

After the workshop, the research team typed up these attributes and posted them on the social media sites; teachers were encouraged to use them to guide student learning as they participated in community projects for sustainability.

\subsubsection{Student involvement in community projects for sustainability}

Before leaving the workshop, the group discussed issues affecting sustainability in their community and identified community involvement projects they may conduct when they returned to their schools. They implemented these projects and reported their progress to the workshop organizers and each other via social media sites.

To facilitate teachers in using solar energy-related activities with their students, the participants could borrow the mini-solar panels 
they used during the workshop. To provide ongoing support for the teachers, the PDP team initiated a Whatsapp and Facebook group. The teachers continued to communicate with each other, including 1025 media posts (e.g., pictures and videos of their students while working on community projects; links to ESD video and photo resources) and 1913 messages through social media (e.g., to explain what they are doing in terms of community projects; to share announcements about other projects and competitions related to ESD). The researchers kept track of their interactions and responded to the comments and questions. Another 97 teachers, who did not attend the workshop, learned about the Education for Sustainability Facebook group and requested to become members; the group currently has 136 members.

Twenty-three projects were completed by the teachers; several were achieved by teams from the same school. They worked with other subject area teachers, mainly science, art, music, and language arts. It was evident that most teachers replicated some of the activities they conducted during the workshop. The mini-solar panels were borrowed by three of the teachers and their students were able to design and race solar cars. Many had students develop solar ovens. Other teachers went beyond what they experienced and developed more extensive activities for their students. They advanced the theme of energy by focusing on consumption in the schools and launched energy saving campaigns. They deepened their practice of place-based education through school gardening and litter cleanup activities. They involved other disciplines by integrating music and community speaking into their projects.

\subsubsection{Project fair}

On May 7, 2016 the participants came to a project fair in Ankara and shared their community involvement projects with each other. Some of the teachers brought students with them to present their projects. To highlight the various foci of the projects, several are briefly described below. Each description includes the project name and a brief overview.

- Biotechnology and food. One school in Istanbul conducted a project that compared natural and human-engineered strategies to produce food.

- Root targets with nature. Students in another school in Istanbul embedded seeds in paper that they recycled.

- Sustainable school, sustainable street. One school in the outskirts of Istanbul launched a poster campaign to promote their classmates to turn off the lights when not in use.

- My battery-powered car is working with solar energy. A school in Ankara conducted a solar car and oven competition.

- Why should I care about the world? In a school in southern Turkey, students used recycled materials to build garbage and recycling containers.

- Waste materials are used again and not becoming garbage. In a school in southeastern Turkey, created shopping bags and clothes from recycled materials.

- Hand in hand for sustainable life. A boarding school located in central Anatolia conducted a number of projects including art from recycling materials, installing solar panels in the school, and journaling about personal plans for a sustainable future.

During the project fair in May, the teachers emphasized the importance of follow-up support and communicating through social media. In the literature, researchers have noted the importance of teacher communication and networking (McClam and Diefenbacher, 2015; Paul and Volk, 2002). Studies have begun to investigate the role of social media for teacher networking and support (Adams and Gynnild, 2013; Robelia et al., 2011).

\section{Research questions and design}

The following research questions guided the investigations for this study:

- Is there a significant difference between in-service teachers' systems thinking scale scores before and after the professional development program?

- How do teachers' concept maps illustrate interactions of the environment, economy and society?

Through the workshop and projects, teachers gained many experiences related to Education for Sustainable Development. A mixed-methods research design was used to enhance the breadth and depth of our understanding the participants' systems thinking (Johnson et al., 2007).

Quantitative data was collected from a systems thinking scale that was administered at the beginning and end of the workshop. Supplementary qualitative data came from analysis of concept maps teachers created near the end of the workshop. Their maps were to show how different workshop activities were connected to each other. They were given directions that their graphic organizer should include all the activities they experienced in the workshop and to provide explanations why they think one activity (e.g., reusing discarded items) might be related to another (e.g., touring a green building).

\subsection{Systems thinking scale (STS)}

To analyze changes in teachers' systems thinking skills, the researchers used a scale that was developed by Moore et al. (2010). This instrument (see Appendix) has 20 items related to system interdependencies and was administered as a paper and pencil questionnaire before and after the workshop. Participants provided responses to the items on a Likert-type scale: $0=$ Never, $1=$ Seldom, $2=$ Some of the time, $3=$ Often, and $4=$ Most of the time. Item scores are summed to provide a STS score that can range from 0 to 80 . There are no reverse coded items.

The instrument was originally written in English and then translated into Turkish. After drafting the instrument, an expert in survey design reviewed it to check for bias and ambiguity. The instrument was piloted with three alumni to examine construct validity. In this study, the reliability check with Cronbach's alpha resulted in the score of 0.811 for pre-test and 0.886 for the post-test $(N=39)$ by using SPSS.

\subsection{Concept map rubric}

Concept maps have often been used to assess systems thinking (Fisher, 2011; Plate, 2010; Sweeney and Sterman, 2000). For the current study, the researchers analyzed the concept maps (CM) teachers created by adapting a rubric developed by Karaarslan (2016). Analysis of concept maps was based on the components of the system (the number of components were counted), the number of connections (a measure of interrelationships was counted and checked whether the connections are correct or not) and hidden dimensions. The two systems thinking criteria and associated assessment levels are listed below:

- Identifying components and of a system also connections among them

1. Mastery: CM shows most of the components and connections in the system

2. Developing: CM shows some of the components and connections in the system 
3. Emergent: $\mathrm{CM}$ shows some components of the system but connections are not clearly showed

- Recognizing hidden dimensions

1. Mastery: CM shows most of the hidden dimensions clearly

2. Developing: $\mathrm{CM}$ shows some hidden dimensions

3. Emergent: $\mathrm{CM}$ does not show any hidden dimensions

For the analysis, one researcher applied the rubric to the concept maps. Inter-rater reliability was used to cross-check analysis with the rubric (Tinsley and Brown, 2000); this involved another expert in ESD repeating the analysis with 19 of the maps. To prepare for the analysis and cross-check, the researcher and an expert held meetings about the study and the structure of the rubric. They reviewed a sample concept map to understand the rubric levels and develop strategies for compliance. Simple statistics determined there was an acceptable level of $92 \%$ consistency between the raters (Miles and Huberman, 1994).

\section{Results and discussion}

\subsection{Developing teachers' systems thinking skills}

The total mean scores of the 20 Likert scale questions in the STS administered before and after the workshop were compared through a paired samples $t$-test using SPSS. The results revealed a statistically significant difference between the pre-test mean scores of the teachers $(M=67.9, S D=6.91)$ and their post-test mean scores $(M=72.8, S D=6.92): t(37)=-6.529 p<0.05$. Pre- and postworkshop mean responses and $t$-test results are given in Table 1.

These findings piqued the interest of the researchers because the teachers who attended the workshop already had a strong interest in sustainability and their pre-test scores indicated they frequently used systems thinking skills. For example, on the questionnaire they indicated that they often "think of problems at hand as a series of connected issues" and "think that systems are constantly changing." Yet, after the workshop, they agreed with these statements more strongly.

The researchers were interested in learning what aspects of the workshop may have contributed to this increase. During the workshop, hands-on activities such as designing a solar oven and car may have encouraged participants to think more holistically about connections between the environment and the economy. Another activity teachers did that possibly contributed to their systems thinking skills was bird watching. One aim of this activity was to introduce teachers to a concept called place-based education (PBE). Through PBE, teachers should use local environments as a resource for their curriculum implementation (Smith, 2007; Sobel, 2004). When teachers were observing local birds, they learned that many of these birds migrate between Africa and Europe and realized how actions of one country or region could affect pathways and welfare of birds in areas hundreds of miles away.

\subsection{Teachers' concept maps regarding the relationships among the activities that were conducted}

The researchers analyzed participants' concept maps to gain further insights into how workshop activities may have contributed to systems thinking skills. In particular, reviewing concept maps showed how teachers perceived the activities they experienced and to what extent they recognized systemic interconnections among the activities.

Thirty-four teachers completed the concept maps to illustrate their understanding of connections among workshop activities. The rubric criteria helped evaluate to what extent the maps reflected teachers' systems thinking. The majority of the teachers' concept maps looked complex, but analysis revealed that some systemic understandings still needed to be developed. In these cases, the participants had a tendency to draw linear or hierarchical maps.

Based on the rubric criteria "identifying components of a system and also connections among them," $26 \%$ of the $\mathrm{CM}(\mathrm{n}=9)$ were at the emerging level, 50\% ( $\mathrm{n}=17)$ were at the developing level; and $24 \%(n=8)$ were at the mastery level. Examples of CMs that illustrate these three levels are shown in Figs. 2-4 respectively. Teachers mainly identified the components of a system and grouped them under economy, environment, and society terms, but most did not make connections among these components. Some teachers did make connections, but they forgot to or chose not to provide labels that explained the relationships. The teachers frequently connected economy and environment concepts, but most did not indicate how the environmental law activities were related to the other workshop activities.

The second rubric item, "recognizing hidden dimensions," showed that $24 \%$ of the $\mathrm{CM}(\mathrm{n}=8)$ were at the emerging level, $54 \%$ of them $(n=19)$ were at the developing level, and $22 \%$ of them

Table 1

Comparison of pre and post scores of each item at STS.

\begin{tabular}{|c|c|c|c|c|c|}
\hline Scale item & & Mean & SD & $\mathrm{t}$ & $\mathrm{df}$ \\
\hline Pair 1 & Pre1 - Post1 & -0.39474 & 0.59455 & $-4.093^{*}$ & 37 \\
\hline Pair 2 & Pre2 - Post2 & -0.34211 & 0.84714 & $-2.489^{*}$ & 37 \\
\hline Pair 3 & Pre3 - Post3 & -0.23684 & 0.58974 & $-2.476^{*}$ & 37 \\
\hline Pair 4 & Pre 4 - Post 4 & -0.31579 & 0.70155 & $-2.775^{*}$ & 37 \\
\hline Pair 5 & Pre5 - Post5 & -0.52632 & 1.26783 & $-2.559^{*}$ & 37 \\
\hline Pair 6 & Pre6 - Post6 & -0.31579 & 0.70155 & $-2.775^{*}$ & 37 \\
\hline Pair 7 & Pre7 - Post7 & -0.18421 & 0.56258 & -2.018 & 37 \\
\hline Pair 8 & Pre8 - Post8 & -0.42105 & 0.72154 & $-3.597^{*}$ & 37 \\
\hline Pair 9 & Pre9 - Post9 & -0.47368 & 0.92230 & $-3.166^{*}$ & 37 \\
\hline Pair 10 & Pre 10 - Post10 & 0.05263 & 0.69544 & 0.467 & 37 \\
\hline Pair 11 & Pre 11 - Post11 & -0.44737 & 0.68566 & $-4.022^{*}$ & 37 \\
\hline Pair 12 & Pre12 - Post12 & -0.21053 & 0.62202 & $-2.086^{*}$ & 37 \\
\hline Pair 13 & Pre13 - Post13 & -0.05263 & 0.80362 & -0.404 & 37 \\
\hline Pair 14 & Pre14 - Post14 & -0.42105 & 0.72154 & $-3.597^{*}$ & 37 \\
\hline Pair 15 & Pre15 - Post15 & -0.44737 & 0.72400 & $-3.809^{*}$ & 37 \\
\hline Pair 16 & Pre 16 - Post16 & -0.50000 & 0.64724 & $-4.762^{*}$ & 37 \\
\hline Pair 17 & Pre17 - Post17 & -0.50000 & 1.03323 & $-2.983^{*}$ & 37 \\
\hline Pair 18 & Pre 18 - Post18 & -0.21053 & 0.87481 & -1.483 & 37 \\
\hline Pair 19 & Pre19 - Post19 & -0.28947 & 0.86705 & $-2.058^{*}$ & 37 \\
\hline Pair 20 & Pre20 - Post20 & -0.36842 & 0.75053 & $-3.026^{*}$ & 37 \\
\hline
\end{tabular}

*p $<0.05$. 


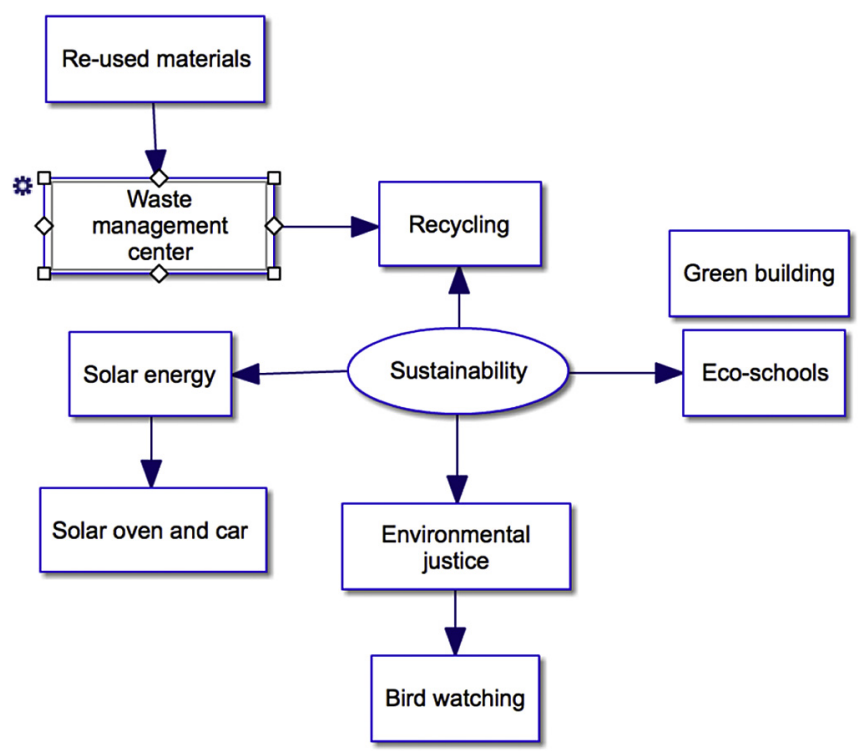

Fig. 2. Example of an emerging concept map.

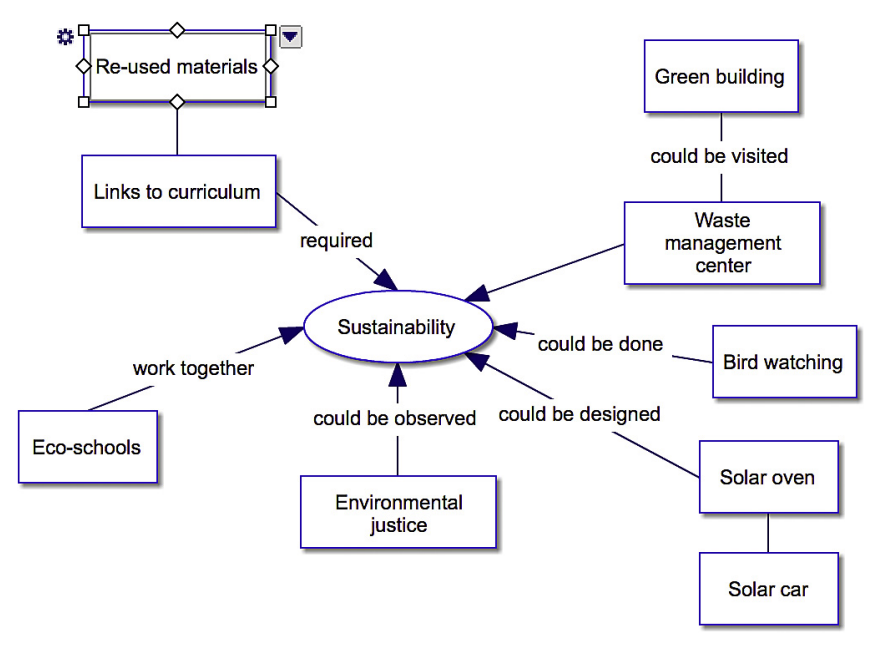

Fig. 3. Example of a developing concept map.

$(n=7)$ were at the mastery level. All the maps illustrated connections between the ESD entities environment (local ecosystems) and economy (alternative energy resources). While most maps included society, very few noted issues related to social justice. Furthermore, only some of the teachers clearly identified hidden dimensions that affected multiple connections among items in their maps. Some subtle, yet influential, dimensions include interdisciplinary education, inter-generational thinking, and food production.

Therefore, even though the quantitative data indicated that teachers' systems thinking skills increased, the qualitative data revealed that some of these skills are still emerging. Nevertheless, the concept maps did show that teachers were able to find relationships among the workshop activities and relate them all to energy.

\section{Conclusion}

This study addresses a gap in the literature by presenting and analyzing the outcomes of a professional development program in
ESD for in-service teachers. As discussed in the theoretical background, many studies regarding teacher preparation for ESD focus on pre-service teachers; there needs to be more ESD programs that work with practicing teachers. Another contribution of this study to the field of ESD is seen by revisiting the theoretical background used to develop the PDP. The study showed how a theme-based workshop can be designed that combines three aspects of ESD and that provides teachers with a holistic approach to professional development for sustainability education. The researchers used the Interpretivist approach to systems thinking as presented by Porter and Córdoba (2009). Teachers were provided an opportunity to examine their place within community systems; they investigated their place by participating in activities related to ESD knowledge, skills, and dispositions (head, hands, and heart); concepts outlined by Sipos et al. (2008). Finally, these experiences were connected through the interdisciplinary approach advocated by Steiner and Posh (2006).

A core purpose of the workshop was to motivate practicing teachers to integrate sustainability concepts and skills, particularly systems thinking, into their classroom lessons. Through this PDP, teachers were provided with opportunities to develop ESD-related competencies such as working in an interdisciplinary manner, coping with conflicts, participating collectively in decision making, and thinking creatively (Bertschy et al., 2013; De Haan, 2010; Sipos et al., 2008; Wiek et al., 2011).

The workshop included a variety of energy-related activities to involve teachers in learning how the environment, society, and economy all play a role in sustainable development. Using this theme helped develop systems thinking skills by challenging participants to interpret interactions and connections among various aspects of their lives (Porter and Córdoba, 2009).

The collected and analyzed data sought to examine how teachers' systems thinking changed as a result of the PDP. The teachers who attended this workshop already had an awareness of and interest in sustainability. They recycled and appreciated the importance of saving energy. Their advanced system thinking skills were revealed in their responses to an instrument administered before the workshop. The items in the questionnaire focused on system thinking skills in general (e.g., seeing relationships, cause and effect, recognizing patterns) and were not designed specifically for this workshop or about ESD in particular. Although the participants' responses indicated they already had strong systems thinking skills in the pre-workshop questionnaire, the postworkshop survey results showed that their systems thinking skills significantly increased by the end of the program.

A limitation of this study is that participants completed the questionnaire directly at the end of the workshop. It is not known if their systems thinking skills would be as strong weeks or months later. If funds were available, it would be advantageous to conduct a longitudinal study of workshop outcomes and learn if participants changed the way they conduct their lessons and interactions with students. Adding additional measurement tools to the current study would help gain greater insights into the development of teachers' system thinking skills and changes in their practice. Even short term measures such as interviews would enhance the findings. Follow up questions and discussions with teachers might help the researchers better relate the questionnaire items to the workshop results.

Another limitation is that there was no formal research conducted relevant to the projects teachers conducted with students nor was there an analysis of the social media they used. During the project fair when teachers presented the projects they conducted with students, the researchers did perceive that the PDP helped participants see connections among energy issues in their home, school, and community. During their presentations, the teachers 


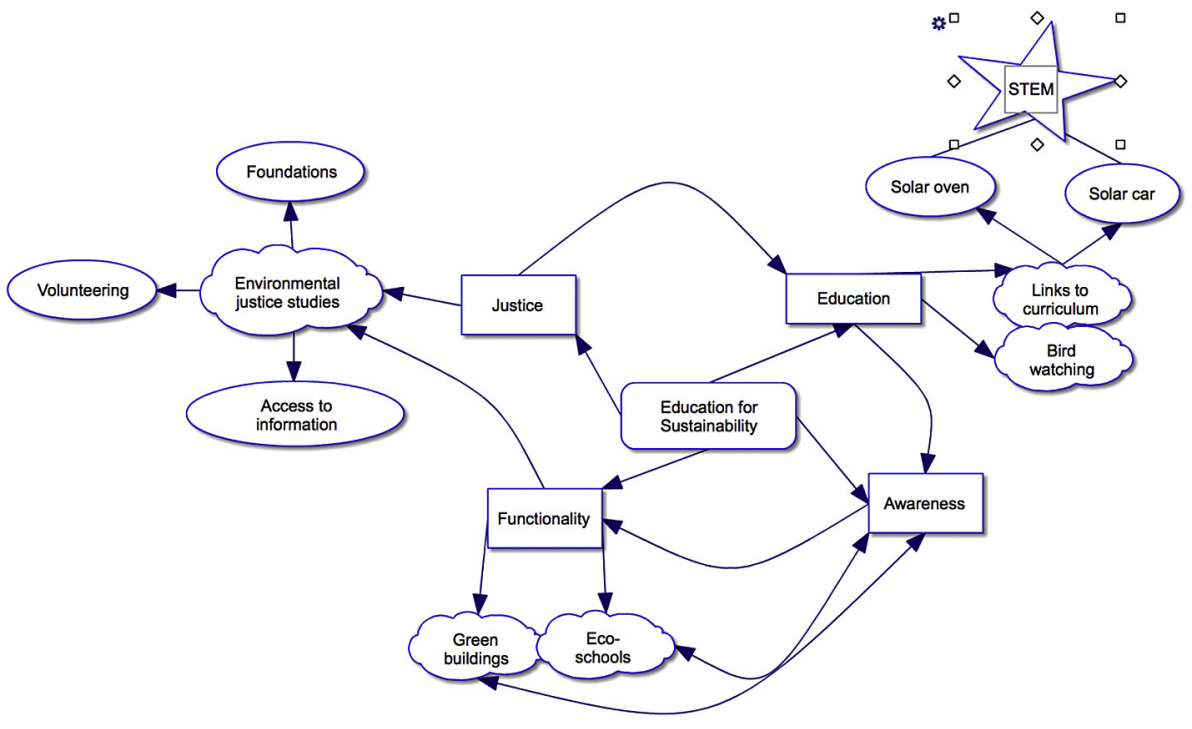

Fig. 4. Example of a mastery concept map.

shared how knowledge, skills, and dispositions related to sustainability helped link a variety of subject areas to each other throughout the school day. Having an external reviewer who could observe teachers in their practice would confirm the researchers' perceptions and provide further insights into how the projects reflected teachers' systems thinking skills.

Despite these research limitations, the PDP was successful. All the teachers who participated in the PDP involved students in projects to address sustainability issues in their community. This study showcases how theme-based workshops can be used for teacher professional development in ESD. During the PDP, one theme (energy) was the needle that wove the golden thread of sustainability through the teachers' learning experiences. Teachers were able to pick up this needle and, when they involved students in place-based community projects, continue to weave the thread through student learning. It is the hope of the researchers that the participants will carry on sharing the information they learned from the PDP with their students, reaching more learners every year. Further teacher professional development programs could adopt a similar strategy, using the same or a different ESD topic (e.g., health or water) as a workshop theme. Carefully and purposefully weaving more and more golden threads through our education systems will help create a sturdy tapestry of learning and action for a sustainable future.

\section{Acknowledgements}

The Scientific and Technological Research Council of Turkey financially supported this research and the project number was $115 \mathrm{~B} 447$.

\section{Appendix}

\section{0 item Systems Thinking Scale}

\section{Instructions:}

Making Improvement

Please read each of the statements and place an " $\mathrm{x}$ " in the answer box that indicates frequency of agreement with the statement:

When I want to make an improvement ...

1. I seek everyone's view of the situation.

2. I look beyond a specific event to determine the cause of the problem.

3. I think understanding how the chain of events occur is crucial.

4. I include people in my work unit to find a solution.

5. I think recurring patterns are more important than any one specific event.

6 . I think of the problem at hand as a series of connected issues.

7. I consider the cause and effect that is occurring in a situation.

8. I consider the relationships among co- workers in the work unit.

9. I think that systems are constantly changing.

10. I propose solutions that affect the work environment, not specific individuals.

11. I keep in mind that proposed changes can affect the whole system.

12. I think more than one or two people are needed to have success.

13. I keep the mission and purpose of the organization in mind.

14. I think small changes can produce important results.

15. I consider how multiple changes affect each other.

16. I think about how different employees might be affected by the improvement.

17. I try strategies that do not rely on people's memory.

18. I recognize system problems are influenced by past events.

19. I consider the past history and culture of the work unit.

20. I consider that the same action can have different effects over time, depending on the state of the system. 


\section{References}

Adams, P., Gynnild, A., 2013. Environmental messages in online media: the role of place. Environ. Commun. 7 (1), 113-130. http://dx.doi.org/10.1080/ 17524032.2012 .754777

Alkis, S., 2008. Education for sustainable development in Turkey. Int. Schulbuchforsch. 30 (2), 597-608.

Arbuthnott, K.D., 2009. Education for sustainable development beyond attitude change. Int. J. Sustain. High. Educ. 10 (2), 152-163.

Arnold, R.D., Wade, J.P., 2015. A definition of systems thinking: a systems approach. Procedia Comput. Sci. 44, 669-678.

Assaraf, O.B.Z., Orion, N., 2005. Development of system thinking skills in the context of earth system education. J. Res. Sci. Teach. 42 (5), 518-560.

Ateskan, A., 2009. Online Professional Development for Teachers. VDM Verlag Dr. Müller Aktiengesellschaft \& Co. KG, Germany.

Balgopal, M.M., Wallace, A.M., 2009. Decisions and dilemmas: using writing to learn activities to increase ecological literacy. J. Environ. Educ. 40 (3), 13-26.

Bertschy, F., Künzli, C., Lehmann, M., 2013. Teachers' competencies for the implementation of educational offers in the field of education for sustainable development. Sustainability 5 (12), 5067-5080.

Binkley, M., Erstad, O., Herman, J., Raizen, S., Ripley, M., Miller-Ricci, M., Rumble, M., 2012. Defining twenty-first century skills. In: Griffin, P., McGaw, B., Care, E. (Eds.), Assessment and Teaching of 21st Century Skills. Springer, Netherlands, pp. 17-66.

Cabrera, D., Colosi, L., Lobdell, C., 2008. Systems thinking. Eval. Program Plan. 31, 299-310.

Cavas, B., Ertepinar, H., Teksoz, G., 2014. Sustainability in schools of education in Turkey: in the words of lecturers. J. Baltic Sci. Educ. 13 (4), 469-482.

Conca, K., 2001. Consumption and environment in a global economy. Glob. Environ. Polit. 1 (3), 53-71.

De Haan, G., 2010. The development of ESD-related competencies in supportive institutional frameworks. Int. Rev. Educ. 56 (2-3), 315-328.

Dobers, P., Strannegård, L., 2005. Design, lifestyles and sustainability. Aesthetic consumption in a world of abundance. Bus. Strategy Environ. 14 (5), 324-336.

Dyment, J.E., Davis, J.M., Nailon, D., Emery, S., Getenet, S., McCrea, N., Hill, A., 2014 The impact of professional development on early childhood educators' confidence, understanding and knowledge of education for sustainability. Environ. Educ. Res. 20 (5), 660-679. http://dx.doi.org/10.1080/13504622.2013.833591.

Ferreira, J., Ryan, L., 2012. Working the system: a model for system-wide change in pre-service teacher education. Aust. J. Teach. Educ. 37, 29-45. http://dx.doi.org/ 10.14221/ajte.2012v37n12.3.

Ferreira, J., Ryan, L., Davis, J., Cavanagh, M., Thomas, J., 2009. Mainstreaming Sustainability into Pre-service Teaching Education in Australia. Australian Government Department of the Environment, Water, Heritage and the Arts, Canberra, Australia. Retrieved from. http://aries.mq.edu.au/projects/ preservice2/files/Pre-Service_Teacher_Ed2.pdf.

Ferreira, J., Ryan, L., Tilbury, D., 2007. Planning for success: factors influencing change in teacher education. Aust. J. Environ. Educ. 23, 45-55.

Fisher, D.M., 2011. "Everybody thinking differently": K-12 is a leverage point. Syst. Dyn. Rev. 27 (4), 394-411.

Frisk, E., Larson, K.L., 2011. Educating for sustainability: competencies \& practices for transformative action. J. Sustain. Educ. 2, 1-20.

Gadotti, M., 2010. Reorienting education practices towards sustainability. J. Educ Sustain. Dev. 4 (2), 203-211.

Gruenewald, D.A., 2003. Foundations of place: a multidisciplinary framework for place-conscious education. Am. Educ. Res. J. 40 (3), 619-654.

Heller, M.C., Keoleian, G.A., 2003. Assessing the sustainability of the US food system: a life cycle perspective. Agric. Syst. 76 (3), 1007-1041.

Hopkins, C.A., McKeown, R., 1999. Education for sustainable development. In: Forum for Applied Research and Public Policy, vol. 14, No. 4. University of Tennessee, Energy, Environment and Resources Center, p. 25.

Johnson, R., Onwuegbuzie, A., Turner, L., 2007. Toward a definition of mixed methods research. J. Mix. Methods Res. 1 (2), 112-133.

Karaarslan, G., 2016. Science Teachers as ESD Educators: an Outdoor ESD Model for Developing Systems Thinking Skills (Unpublished Doctoral Dissertation). Middle East Technical University, Turkey.

Karaman, A.C., 2014. Community service learning and the emergence of systems thinking: a teacher education project in an urban setting in Turkey. Syst. Pract. Action Res. 27 (5), 485-497.

Kaya, M.F., Tomal, N., 2011. Sosyal bilgiler dersi ögretim programının sürdürülebilir kalkınma eğitimi açısından incelenmesi [Examination of the social sciences education program in the frame of sustainable development training]. Eğitim Bilimleri Araștırmaları Dergisi - J. Educ. Sci. Res. 1 (2), 49-65.

Kilinc, A., Aydin, A., 2013. Turkish student science teachers' conceptions of sustainable development: a phenomenography. Int. J. Sci. Educ. 35 (5), 731-752.

Knapp, C.E., 2005. The 'I-Thou' relationship, place-based education, and aldo leopold. J. Exp. Educ. 27 (3)

Loucks-Horsley, S., Love, N., Stiles, K., Mundry, S., Hewson, W., 2003. Designing Professional Development for Teachers of Science and Mathematics, second ed. Corwin Press, Thousand Oaks, CA.

McClam, S., Diefenbacher, L., 2015. Over the fence: learning about education for sustainability with new tools and conversation. J. Educ. Sustain. Dev. 2 (9), 126-136.
McKeown, R., 2012. Teacher education 1992 and 2012: reflecting on 20 years. J. Educ. Sustain. Dev. 1 (6), 37-41.

Miles, M.B., Huberman, A.M., 1994. Qualitative Data Analysis: an Expanded Sourcebook, second ed. Sage Publications, Thousand Oaks.

Moore, S.M., Dolansky, M.A., Singh, M., Palmieri, P., Alemi, F., 2010. The SystemsThinking Scale (Unpublished manuscript).

Nguyen, N.C., Graham, D., Ross, H., Maani, K., Bosch, O., 2012. Educating systems thinking for sustainability: experience with a developing country. Syst. Res. Behav. Sci. 29 (1), 14-29.

Ozel, A., Senyurt, S., Ozturk, M., Ozel, E., 2013. Turkish geography prospective teachers perspective and attitudes of sustainable development. J. Environ. Prot. Ecol. 14, 1273-1282.

Paul, G., Volk, T.L., 2002. Ten years of teacher workshops in an environmental problem-solving model: teacher implementation and perceptions. J. Environ. Educ. 33 (3), 10-20. http://dx.doi.org/10.1080/00958960209600810.

Plate, R., 2010. Assessing individuals' understanding of nonlinear causal structures in complex systems. Syst. Dyn. Rev. 26 (1), 19-33.

Porter, T., Córdoba, J., 2009. Three views of systems theories and their implications for sustainability education. J. Manag. Educ. 33 (3), 323-347.

Powers, A., 2005. An evaluation of four place-based education programs. J. Environ. Educ. 35 (4), 17-32.

Rauch, F., Steiner, R., 2013. Competences for education for sustainable development in teacher education. CEPS J. Cent. Educ. Policy Stud. J. 3 (1), 9.

Rees, W.E., 2008. Human nature, eco-footprints and environmental injustice. Local Environ. 13 (8), 685-701.

Rieckmann, M., 2012. Future-oriented higher education: which key competencies should be fostered through university teaching and learning? Futures 44 (2), 127-135.

Robelia, B.A., Greenhow, C., Burton, L., 2011. Environmental learning in online social networks: adopting environmentally responsible behaviors. Environ. Educ. Res. 17 (4), 553-575.

Sağdıç, A., Şahin, E., 2016. A closer look into Turkish elementary teachers regarding their beliefs on education for sustainable development. Int. Electron. J. Environ. Educ 6 (2), 141-155.

Sandri, O.J., 2013. Threshold concepts, systems and learning for sustainability. Environ. Educ. Res. 19 (6), 810-822.

Scott-Cato, M., 2009. Green Economics. Earthscan, London.

Sheth, J.N., Sethia, N.K., Srinivas, S., 2011. Mindful consumption: a customer-centric approach to sustainability. J. Acad. Mark. Sci. 39 (1), 21-39.

Senge, P., Cambron-McCabe, N., Lucas, T., Smith, B., Dutton, J., Kleiner, A., 2000. Schools that Learn: a Fifth Discipline Fieldbook for Educators, Parents, and Everyone Who Cares about Education. Doubleday, New York.

Shriner, M., Schlee, B., Hamil, M., Libler, R., 2009. Creating teachers' perceptual, behavioral, and attitudinal change using professional development workshops. Teach. Dev. 13 (2), 125-134. http://dx.doi.org/10.1080/13664530903043947.

Sipos, Y., Battisti, B., Grimm, K., 2008. Achieving transformative sustainability learning: engaging head, hands and heart. Int. J. Sustain. High. Educ. 9 (1), 68-86.

Comenius 2.1 Project 118277-CP-1-2004-BE-Comenius-C2. In: Sleurs, W. (Ed.), 2008. Competencies for ESD (Education for Sustainable Development) Teachers: a Framework to Integrate ESD in the Curriculum of Teacher Training Institutes, vol. 1, p. 2008.

Smith, G.A., 2007. Place-based education: breaking through the constraining regularities of public school. Environ. Educ. Res. 13 (2), 189-207.

Sobel, D., 2004. Place-based Education: Connecting Classrooms and Communities. The Orion Society, Barrington, Massachusetts.

Steiner, G., Posh, A., 2006. Higher education for sustainability by means of transdiciplinary case studies: an innovative approach for solving complex, realworld problems. J. Clean. Prod. Sustain. High. Educ. What is Happen. 14 (9-11), 877-890.

Summers, D., 2013. Education for sustainable development in initial teacher education: from compliance to commitment-sowing the seeds of change. J. Educ. Sustain. Dev. 7 (2), 205-222.

Sweeney, L.B., Sterman, J.D., 2000. Bathtub dynamics: initial results of a systems thinking inventory. Syst. Dyn. Rev. 16 (4), 249-286.

Sweeney, L.B., Sterman, J.D., 2007. Thinking about systems: student and teacher conceptions of natural and social systems. Syst. Dyn. Rev. 23 (2-3), 285-311.

Tanriverdi, B., 2009. Analyzing primary school curriculum in terms of sustainable environmental education. Educ. Sci. 34 (151), 89-103.

Tinsley, H.E., Brown, S.D., 2000. Multivariate statistics and mathematical modeling. In: Tinsley, H.E., Brown, S.D. (Eds.), Handbook of Applied Multivariate Statistics and Mathematical Modeling. Academic Press, San Diego, CA, pp. 8-34.

Turkish Republic Ministry of Development, 2012. Turkey's Sustainable Development Report: Claiming the Future. Ministry of Development, Ankara, Turkey.

Turkish Republic Ministry of Development, 2015. Turkey's Sustainable Development Pathway towards Agenda 2030. Ministry of Development, Ankara, Turkey.

UNESCO, 2014. Shaping the Future We Want: Education for Sustainable Development (2005-2014) Final Report. United Nations Educational, Scientific, and Cultural Organization, Paris.

Venkataraman, B., 2009. Education for sustainable development. Environ. Sci. Policy Sustain. Develop. 51 (2), 8-10.

Warren, A., Archambault, L., Foley, R.W., 2014. Sustainability Education Framework for Teachers: developing sustainability literacy through futures, values, 
systems, and strategic thinking. J. Sustain. Educ. 6, 1-14.

Wiek, A., Bernstein, M., Foley, R.W., Cohen, M., Forrest, N., Kuzdas, C., ... Keeler, L.W., 2015. Operationalising Competencies in Higher Education for Sustainable Development. Handbook of Higher Education for Sustainable Development. Routledge.
Wiek, A., Withycombe, L., Redman, C.L., 2011. Key competencies in sustainability: a reference framework for academic program development. Sustain. Sci. 6 (2), 203-218.

Worts, D., 2006. Fostering a culture of sustainability. Museums Soc. Issues 1 (2), $151-172$ 